\title{
İlkokul Öğrencilerinin Müziğe Yönelik Güdülerinin Müziksel Etkinlikleri Gerçekleştirme Durumlarına Göre İncelenmesi
}

\author{
Doç. Dr. Sabahat BURAK* \\ Akdeniz Üniversitesi, Eğitim Fakültesi, Temel Eğitim Bölümü, Antalya / Türkiye, \\ buraksabahat@gmail.com, ORCID: 0000-0002-8210-8175 \\ Gülcan ATEŞ \\ Özel Antalya Lara Bahçeşehir İlkokulu, Antalya / Türkiye, \\ gulcan.ates07@gmail.com, ORCID: 0000-0003-4735-2428
}

\section{$\ddot{\mathbf{O z}}$}

$\mathrm{Bu}$ araştırmada, ilkokul öğrencilerinin müzik dinleme, şarkı söyleme ve çalgı çalmaya yönelik güdülerinin onların evdeki müziksel ortamları, öğretmen ve kendilerinin müzik etkinliklerini gerçekleştirme durumlarına göre anlamlı farklılıklar gösterip göstermediğinin ortaya çıkarılması amaçlanmıştır. İliş̧kisel tarama modelinde olan bu araştırmanın katılımcıları, 2019-2020 eğitim-öğretim yılında Antalya ilinin Muratpaşa, Konyaaltı, Kepez ilçelerinden seçilen birer ilkokulda öğrenim görmekte olan ilkokul 2, 3 ve 4. sınıf öğrencilerinden oluşmaktadır. Araştırmada veriler "Müzik Dinlemeye Yönelik Güdü Ölçeği”, "Şarkı Söylemeye Yönelik Güdü Ölçeğì", "Çalgı Çalmaya Yönelik Güdü Ölçeği” ve araştırmacı tarafından hazırlanan Kişisel Bilgi Formu kullanılarak toplanmıştır. Araştırmaya 350 ilkokul öğrencisi katılmıştır ( $\mathrm{n}=350)$. Araştırmada veriler, betimsel istatistikler, Kolmogorov-Smirnov Testi, Pearson korelasyon katsayısı, etki büyüklüğünün (eta-kare) hesaplaması ve $t$ Testi analizi ile çözümlenmiştir. Araştırma bulgularına göre öğrencilerin bireysel müzik etkinliklerini gerçek- 
leştirme durumlarına göre; çalgı çalan, müzik dinleyen, şarkı söyleyen, müzik topluluğuna üye olan, çalgısı olan ve evinde müzikli oyuncağı bulunan öğrencilerin müzik dinleme, şarkı söyleme ve çalgı çalmaya yönelik güdülerinin diğer öğrencilere göre anlamlı düzeyde yüksek olduğu sonucuna ulaşılmıştır. Öğrencilerin evdeki müziksel ortamlarına göre; evinde aile üyelerinden birinin çalgı çaldığ 1 ve aile üyeleri ile birlikte çalgı çalan, müzik dinleyen ve şarkı söyleyen öğrencilerin; müzik dinleme, şarkı söyleme ve çalgı çalmaya yönelik güdüleri diğerlerine göre anlamlı düzeyde yüksektir. Öğrencilerin öğretmenlerinin sınıf içinde gerçekleştirdikleri müziksel etkinliklere göre; derslerde öğretmeni çalgı çalan ve şarkı söyleyen öğrencilerin; müzik dinleme, şarkı söyleme ve çalgı çalmaya yönelik güdülerinin anlamlı düzeyde yüksek olduğu sonucuna ulaşılmıştır.

Anahtar Kelimeler: Müzik; Dinleme; Söyleme; Çalma; Müzik eğitimi.

\title{
Investigation of Primary School Students' Motives
}

\section{toward Music According to Their Musical Activities}

\begin{abstract}
The aim of this research is to reveal whether there is a significant difference in motives of the primary school students' according to musical environment at home, teachers' musical activities, or personal musical activities. The research is a correlational study. The study group consisted of the second, third, and fourth grade students from Muratpaşa, Konyaaltı and Kepez districts of Antalya. Data were collected by using Motive for Listening to Music Scale, Motive for Singing Scale, Motive for Playing Instrument Scale, and Personal Information Form. The research was carried out with 350 students in total $(\mathrm{n}=350)$. Data were analyzed by using descriptive statistics, Kolmogorov-Smirnov Test, Pearson's correlation, effect size and $t$ Test. It was found that according to the individual musical activities; students who play an instrument, sing song or is a member of a musical group, have an instrument or musical toy at home have significantly higher motives for singing, listening a song or playing an instruments compared to the others. According to the musical environments that students have at home; students who have a family member that plays an instrument at home and students who play music, sing songs, listen to music with their families have significantly higher motivations than the others. According to the musical activities, students have in classrooms; students who have teachers that play instruments and sing songs have significantly higher motivation for singing, listening to music and playing instruments than the others.
\end{abstract}

Keywords: Music; Listening; Singing; Playing; Music Education. 


\section{Extended Summary}

\section{Purpose}

The structure, which includes the situations such as giving oneself to an activity, taking time and enjoying it, is considered as "motive" and it is based on needs, goals, interests, values, habits, attitudes and expectations. Since each student is motivated in different ways according to their age group and individual characteristics in music education, the teacher should use different teaching approaches and methods. Motivation has been cited as one of the key features suitable for investigating individual differences, especially in the educational context. Knowing the motivational sources for music in the music education process is one of the factors that will increase the quality of the education given. The purpose of this research is to reveal whether there was a significant difference in motives of the primary school students according to their musical environment at home, teachers' musical activities, or personal musical activities.

\section{Method}

The research was designed as a corelational study. The study group of the research consisted of the second, third and fourth grade students. The schools were in Muratpaşa, Konyaalt1, Kepez districts of Antalya of Turkey. Data were collected by using Motive for Listening to Music Scale, Motive for Singing Scale, Motive for Playing Instrument Scale and Personal Information Form. The research was carried out with 350 students in total $(n=350)$. Data were analyzed by using descriptive statistics, Kolmogorov-Smirnov Test, Pearson's correlation, effect size, and $t$ Test.

\section{Results}

According to the results of the analyses, it was found that motives of the primary school students for listening to music, singing or playing a musical instruments were high. According to the individual musical activities; students who play an instrument, sing or being member of a musical community, have an instrument or musical toy at home had significantly higher motives for singing, listening a song or playing an instruments than the others. According to the musical environments that students have at home; students who have a family member that plays an instrument at home and students who play music, sing songs, listen to music with their families had significantly higher motives compared to the others. According to the musical activities students have in 
clasrooms; students whose teachers play instruments and sing songs had significantly higher motive for singing, listening to music and playing instruments than the others.

\section{Discussion}

It was concluded that the motives of the students who play musical instruments, listen to music, sing, are members of the music community, have instruments and have musical toys at home, towards listening to music, singing and playing instruments were significantly higher than other students. Students' individual participation in musical activities affect their motivation towards music. Based on this finding, it is important for students to be more motivated towards music, to engage in more individual music activities and to get support from friends, teachers and families from their social circles. In order for musical skills brought from birth to emerge and develop in an individual, the individual must interact with certain musical experiences. Musical skills in an individual and inherited from generation to generation cannot turn into musical behaviors unless they interact with the necessary musical environment (Özdemir and Y1ld1z, 2010). In order not to cause this situation, the more the individual is exposed to the musical environment in his environment, the more his motivation towards music will increase.

According to the findings obtained from the research, students who play a musical instrument listen to music and sing with family members in their home; their motives for listening to music, singing and playing an instrument were significantly higher. There was a relationship between the musical environment of the students at home and their motivation towards music. Students in a family who are interested in music and who do musical activities with their family members had stronger motives towards music. For this reason, the more opportunities the family provides for musical activities at home for the child and the family members participate in this, the child's motivation towards music will increase. Kebapçı (2019) concluded that students whose family members are interested in music and students who regularly listen to music with their family members get higher scores on the musical environment scale at home. Similarly, Brand (1986) stated that the musical environment variables in the home increased the musical achievement of the students and that the parents' participation in music affected the children's attitudes towards music. Özmenteş (2012) concluded that there is a relationship between the factors of listening to music and singing at home and their attitudes 
towards music.

According to the findings obtained from the research, the students whose teacher plays the instrument and sings in the lessons; motives for listening to music, singing and playing an instrument were significantly high. According to this, the musical activities of the students in the lessons by the teachers affect their motivations towards music. For this reason, teachers' more frequent use of musical activities can motivate them more towards music. Similarly Sichivitsa (2007) reported that teachers who address both the social and academic needs of their students have improved their attitude towards the classroom as well as their value to music and their motivation to continue musical activities. Özmenteş (2013) stated that teacher-student communication should be one of the most important factors affecting the motivation of teachers and students. Each student can be different in terms of learning style and personal characteristics, and they are motivated in different ways. Additionally, Kocabaş (2000) stated that the music lessons teachers took during their undergraduate period were not sufficient in providing music teaching. Hence, the content and effectiveness of in-service training for classroom teachers may need to be improved.

\section{Conclusion}

As a result of the research; It was understood that the more students participate in music-related activities, the more their motives for music increases.

\section{Giriş}

Müzik eğitimi, temelde, bir müziksel davranış kazandırma, değiştirme ve geliştirme sürecidir (Uçan, 2005). Birey hayatı boyunca, eğitimini sürdürürken ya da günlük hayatını devam ettirirken kendini müzik ortamı içinde bulabilmekte (Öz, 2001), bulunduğu müziksel ortam da aldığı müzik eğitiminin niteliğini etkileyebilmektedir. Müzik eğitimi süresince müziksel kazanımların gerçekleştirilebilmesi için yetenek ve bilişsel yeterlilikler ön plana çıkarken, öğrencilere müzik sevgisi ve beğenisi kazandırma (Uluğbay, 2013), müziğe yönelik tutum, özyeterlilik, ilgi ve güdülenme gibi duyuşsal özelliklerin geliştirilmesinin de önem kazandığ gözlenmektedir (Brand, 1986; Özmenteş, 2012; Youm, 2013).

Bir işe ve etkinliğe kendini verme, zaman ayırma, hoşlanma gibi durumları içinde barındıran yapı "güdü" olarak ele alınmakta ve temelinde ihti- 
yaç, hedef, ilgi, değer, alışkanlık, tutum ve beklentiler bulunmaktadır (Açıkgöz, 2005). Güdü ayrıca, bireye enerji verip davranış için istekli hale gelmesinde etkili olan önemli bir etken olarak tanımlanmakta, (Akbaba, 2006, s.1) güdü sayesinde kişi harekete geçerek bir işi gerçekleştirmek için hazır hale gelmektedir. Atabek (2013), güdünün kişilikle ilişkili bir psikolojik yapı olup bireylerin medya seçimleriyle doğrudan ilişkili olduğunu bildirmiştir. Dolayısıyla güdüler, bireylerin maruz kaldıkları medya örüntülerini ve bu maruz kalışın sonuçlarını belirlemektedir (Atabek, 2013). Bireylerin bir işi gerçekleştirmek ve bu işte başarılı olmak için öncelikle yeterince güdülenmeleri gerekmekle birlikte, müzik eğitimi sürecinde güdülenme, oldukça önemli bir konu olarak görülmektedir (Güleç, 2007). Bununla birlikte, ilkokul döneminde al1nan müzik eğitiminde öğrencilerin bireysel müzik etkinlikleri, evdeki müziksel ortamları, akranlarının ve öğretmenlerinin uyguladıkları müziksel etkinlikler müziğe yönelik güdülerini etkileyebilmektedir. İlkokulda verilen müzik eğitiminde başarıya ulaşmak için öğretmenin müziğe yönelik güdülenmesi gerekmektedir. Öğretmenin güdülenmesi halinde bu durum öğrenciye de yans1yacağından öğrencinin de müziğe güdülenmesi daha kolay ve çabuk gerçekleşebilir. Öğrencilerin müziğe yönelik güdülerini evdeki müziksel ortamları da etkileyebilmektedir. Öğrencilerin müziğe değer verilen ortamda yetişmeleri, ailelerin evde çocuklarının istedikleri zaman müziksel etkinlikler ile uğraşmalarına engel olmamaları ve onları müziğe yönlendirmeleri gerekmektedir (Özmenteş, 2012). Ayrıca öğrencilerin, sosyal çevrelerinden olan akranları tarafindan desteklenip kabul gördüklerinde müziğe daha fazla değer verdikleri görülmüştür (Sichivitsa, 2007).

Müzik eğitiminin bir boyutu olan çalgı eğitimi, bireyin kendisini yakından tanımasını, var olan yeteneklerini ortaya çıkarabilmesini, var olan becerilerini geliştirip, yeni becerilere ulaşmasını sağlayıp bireye bir uğraş sağlar (Uslu, 2006). Çalgı eğitimi, müzik eğitiminin boyutlarından biri olup üst düzey beceriler gerektirmektedir (Özmenteş, 2005). Çalg1 eğitiminde öğrenci öncelikle dinlemeyi öğrenmelidir (Byo, 1990). Dinleme, işitme eğitimiyle mümkün olabilir. Dinleme ve işitme eğitimiyle birlikte şarkının seslendirilmesine şarkı söyleme denir. Şarkı ögretiminde öğretmen, öğrencilerinin fiziksel becerileri, fizyolojik ve psikolojik gelişimlerini göz önünde bulundurmalıdır (Deniz-Nart, 2010). Örneğin kaygı gibi olumsuz duygu durumları bir yandan bireylerin kendilerini geliştirmeye güdülese de bir yandan da performanslarını olumsuz etkilemektedir (Atabek, 2020; Atabek ve ark., 2019). Öğ- 
rencilerin güdü eksikliği başka bir olumsuz duygu durumu olan strese de neden olmaktadır (Burak ve Atabek, 2019). Şarkı seçiminde, seçilen şarkı öğrencilerin ortak ses alanına, gelişim düzeylerine uygun olmalıdır. Seçilen şarkı öğrencilerin ilgisini çekmelidir (Oğul, 2009).

Müzik eğitiminde güdü konusunu ele alan araştırmalar incelendiğinde bu araştırmaların sayıca az olduğu gözlenmiştir. Bilen (1995) araştırmasında, işbirlikli öğrenme yönteminin, müziğe ilişkin güdünün gelişmesinde daha etkili olduğu sonucuna varmıştır. Kocaarslan (2009) ise öğrencilerin müzikal güdü düzeyleri ile müzik dersine ilişkin tutumları arasında anlamlı bir ilişki bulmuştur. Ayrıca güdüyü etkileyen bir diğer etkenin sıklıkla konsere gitmek olduğuna değinmiştir. Bilen (1995) ve Kocaarslan'ın (2009) araştırmalarına göre, öğrencilerin güdüleri bulundukları etkinliklere göre farklılık göstermektedir. Dolayısıyla, müziksel etkinlikler öğrencilerin müziğe yönelik güdülerini etkileyebilmektedir.

Özmenteş (2013) çalg1 öğretmenlerinin çalg1 eğitiminde öğrenci, güdü ve performansına yönelik görüşlerinin ortaya çıkarılması amaçlamıştır. Araştırmanın sonuçlarına göre görüşmeye katılan öğretmenlerin her birinin çalgı eğitiminde güdü ve performans konusunda öğrenci-öğretmen iletişimi, öğrenci ile empati kurabilme ve her öğrenciye farklı yaklaşımlarda bulunabilme konularında birbirleri ile örtüşen fikirlerde bulundukları gözlenmiştir. Ayrıca, iletişim ve öğretmen- öğrenci arasındaki bağ, öğrencilerin çalg1 eğitimindeki performansını ve güdüsünü etkileyebilmektedir.

Girgin (2015) müzik öğretmeni adaylarının bireysel çalgı derslerine yönelik güdülerini belirlemede kullanılabilecek geçerli ve güvenilir bir ölçek geliştirmeyi amaçlamıştır. Parkes ve arkadaşları (2017) ise güdü envanterinin geçerlik ve güvenirliğini ortaya koymayı amaçlamışlardır. İlkokul, ortaokul ve lisedeki müzik öğrenen öğrencilere uygulanan bu ölçek, geçerli ve güvenilir bir ölçme aracı olduğundan müzik öğretmenleri tarafindan öğrencilerin güdü ile ilgili algılarını değerlendirmek için kullanılabilmektedir.

McPherson ve arkadaşları (2015) müzik öğrenenlerin, okuldaki akademik konuları çalışmak için daha çok güdülenip güdülenmeyeceğini, cinsiyet ve sosyoekonomik durumun, okulda müzik öğrenme güdülerini etkileyip etkilemediği belirlenmeye çalışmıştır. Araştırmanın sonucunda, öğrencilerin okul yıllarında, görevlerindeki artan zorluk nedeniyle müzik öğrenmeyle ilgili yeterlilik inançlarında önemli düşüş olduğu, bu durumda öğrencilerin müzik 
çalışmaya karşı güdülenmede zorluk yaşadıkları sonucuna ulaşılmıştır. Cogdill (2015) bir alanyazın tarama çalışması yaparak güdü ve öğrenme alanında bulunulan çalışmaları incelemiş, günümüz müzik dersleri ve öğretmenlik mesleği için çıkarımlarda bulunmayı amaçlamıştır. Öğretmenlerin, öğrencilerinin müzik dersinde başarılı olmaları ve derse devam etmelerine yardımcı olacak stratejiler uygulamaları gerektiği, farklı yaş gruplarında sergilenen farklı güdülenme şekilleri bulunduğu, bu sebeple öğretmenin bu çeşitli yönlerin farkında olarak öğrencilerin müzik potansiyelleri hakkında olumlu inançlar geliştirmesine yardımcı olması gerektiğinin altını çizmiştir (Cogdill, 2015).

Yapılan araştırmalar incelendiğinde, müzik eğitiminde öğrencilerin güdülenebilmeleri için geleneksel yöntemlerin çok fazla etkili olmadığı müzik eğitiminin işbirlikli yöntem gibi öğrencinin süreç içinde daha aktif olduğu yöntemlerle gerçekleştirildiğinde daha etkili ve verimli olduğu sonuçları ortaya çıkmıştır. Geleneksel müzik eğitimi tek başına yeterli olmadığından etkin öğrenme yöntemleri müzik eğitiminde kullanılmalıdır. Öğrenciler, derse ve etkinliğe güdülendiklerinde daha başarılı olduklarından, öğrenme için güdünün etkili bir unsur olduğu söylenebilir. Her öğrenci yaş grubu ve bireysel özelliklerine göre farklı şekillerde güdülendiğinden müzik eğitiminde öğretmen farklı yaklaşım ve yöntemler kullanmalıdır. Güdü, özellikle eğitim bağlamında, bireysel farklılıkları araştırmaya uygun temel özelliklerden biri olarak gösterilmiştir (Atabek, 2019). Böylelikle müzik eğitimi yapacak öğretmenin, her öğrenciye ulaşabilme olasılığı arttığından geleneksel müzik öğretim yöntemleri ile yetinmeyip etkin öğrenme yöntemlerini kullanmalıdır. Bu bağlamda gerçekleştirilen araştırmanın amacı, ilkokul öğrencilerinin müzik dinleme, şarkı söyleme ve çalgı çalmaya yönelik güdülerinin kişisel ve müziksel değişkenler ile ilişkilerinin ortaya konmasıdır. Araştırmada ayrıca ilkokul öğrencilerinin müzik dinleme, şarkı söyleme ve çalgı çalmaya yönelik güdülerinin evdeki müziksel ortam, öğretmenlerinin ve kendilerinin müzik etkinliklerini gerçekleştirme durumları ile ilişkilerinin ortaya çıkarılması amaçlanmıştır. Araştırmanın alt problemleri şu şekildedir:

1. Öğrencilerin müzik dinleme, şarkı söyleme ve çalgı çalmaya yönelik güdüleri onların kişisel değişkenlerine göre (cinsiyet, yaş, sınıf düzeyi) anlamlı farkl111klar göstermekte midir?

2. Öğrencilerin müzik dinleme, şarkı söyleme ve çalgı çalmaya yönelik güdüleri onların müzik etkinliklerine bireysel katılımlarına göre anlamlı farklılıklar göstermekte midir? 
3. Öğrencilerin müzik dinleme, şarkı söyleme ve çalg1 çalmaya yönelik güdüleri onların evdeki müziksel ortamlarına göre anlamlı farklılıklar göstermekte midir?

4. Öğrencilerin müzik dinleme, şarkı söyleme ve çalgı çalmaya yönelik güdüleri onların öğretmenlerinin derslerde müziksel etkinlikleri gerçekleştirme durumlarına göre anlamlı farklılıklar göstermekte midir?

\section{Araștırma Modeli}

\section{Yöntem}

$\mathrm{Bu}$ araştırma, ilkokul öğrencilerinin müzik dinleme, şarkı söyleme ve çalg1 çalmaya yönelik güdülerinin kişisel ve müziksel değişkenler ile ilişkileri ortaya çıkarma amacıyla yapıldığından, ilişkisel tarama modelinde bir araştırmadır. İlişkisel tarama modelinde, ilişkiler ve aralarında bağlantılar incelenmektedir (Büyüköztürk ve ark., 2016, s.24). Bu araştırmada da araştırmanın modeline uygun olarak ilkokul öğrencilerinin; müziğe yönelik güdüleri ile kişisel değişkenler, aile, öğretmen ve müziksel deneyimler arasındaki ilişki incelenmiştir.

\section{Çalışma Grubu}

Bu araştırmanın çalışma grubu, 2019-2020 eğitim-öğretim yılında Antalya ilinin Muratpaşa, Konyaaltı, Kepez ilçelerinden seçilen birer ilkokulda öğrenim görmekte olan 2, 3 ve 4. sınıf öğrencilerinden oluşmaktadır. Araştırma sonuçları, okulların sosyoekonomik özelliklerine göre de incelendiğinden dolayı farklı ilçelerdeki okullar belirlenmiştir. Antalya'nın Kepez (Şelale İlkokulu), Konyaaltı (Doktor Cahit Ünver İlkokulu) ve Muratpaşa (Ahmet Ferda Kahraman İlkokulu) ilçelerinin her birinden birer okul olmak üzere toplamda 3 okul belirlenmiştir. Belirlenen okullarda toplam 350 öğrenciye ölçek uygulamaları yapılmıştır. 350 öğrencinin $\% 51.4$ oranını kız öğrenciler oluştururken \%48.6 oranını erkek öğrenciler oluşturmaktadır. Öğrencilerin ortalama yaşları 9'dur. 2. sınıflar \%29.4, 3. sınıflar \%23.4, 4. sinıflar \%47.1 oranını oluşturmaktadır.

\section{Veri Toplama Araçları}

Araştırmada öğrencilerin müziğe yönelik güdülerini belirlemek için Ateş ve Burak (2019) tarafından geliştirilen Müzik Dinleme, Şarkı Söyleme ve Çalgı Çalmaya Yönelik Güdü Ölçekleri kullanılmıştır. Bu ölçekler ile birlikte öğrencilerin yaş, sınıf seviyeleri, cinsiyet, bireysel, evdeki müziksel ortam, öğretmen ile ilgili diğer müziksel değişkenler ile ilişkilerini tespit etmek amacı ile araştırmacı tarafından hazırlanan Kişisel Bilgi Formu kullanılmıştır. 
Müzik Dinlemeye, Şarkı Söylemeye ve Çalgı Çalmaya Yönelik Güdü Ölçekleri, Ateş ve Burak tarafından 2019 yılında ilköğretim 2, 3, 4. sınıf düzeyinde öğrenim görmekte olan öğrencilerin müzik dinlemeye yönelik güdülerini belirlemek üzere geliştirilmiştir. 3'lü likert tipinde hazırlanan ölçek maddelerinde cevaplar "Katılmıyorum (1)", "Az Kat1liyorum (2)", "Kat1lıyorum (3)" olarak derecelendirilmiştir. Ölçeklerin geçerlik ve güvenirlik çalışmaları toplam 154 öğrencinin katılımıyla gerçekleştirilmiştir. Ölçeklerin geçerliği içerik ve yapı geçerliği olmak üzere iki alanda sağlanmaya çalışılmıştır. İçerik geçerliğinin sağlanması amacı ile ölçekler, müzik eğitimi, eğitim teknolojisi, çocuk gelişimi ve rehberlik ve psikolojik danışmanlık alanında görev yapan öğretim üyelerinden oluşan uzman grubu tarafından incelenmiştir. Ölçeğin müziğin alt boyutlarını ne derece kapsadığı, öğrencilerin bu alandaki güdülerini tespit için yeterli olup olmadığı ve ölçek maddelerinin açık, anlaşılır ve ölçülmek istenen örneklem grubuna olan uygunluğu ile ilgili geri dönütler alınmıştir.

\section{Kişisel Bilgi Formu}

Kişisel Bilgi Formu, araştırmaya katılan öğrencileri tanımayı sağlayarak "Müzik Dinleme, Şarkı Söyleme ve Çalgı Çalmaya Yönelik Güdü Ölçeğì" ile ilişkilendirilecek bilgileri elde etmeye yarayan kapalı uçlu sorulardan ve 4 bölümden oluşmaktadır. Birinci bölümde öğrencinin müziksel deneyimleri ile ilgili 7 soru, ikinci bölümde öğrencilerin evdeki müziksel ortamları ile ilgili 6 soru, üçüncü bölümde öğrencilerin arkadaşlarının müziksel deneyimleri ve arkadaşlarıyla birlikte yaptıkları müziksel faaliyetler ile ilgili 6 soru ve son bölüm olan dördüncü bölümde öğrencilerin, öğretmenlerinin derslerdeki müziksel faaliyetleri ile ilgili 7 soru olmak üzere toplam 26 sorudan oluşmaktadır. Kişisel Bilgi Formu'ndaki sorular araştırmacı tarafından araştırmaya katılan öğrencilerin belirlenen özelliklerini (yaş, cinsiyet, sınıf, bireysel müziksel deneyim, evdeki müzik ortamı, öğretmen ile ilgili müziksel ortam) tanımaya yönelik hazırlanmıştır.

\section{Müzik Dinlemeye Yönelik Güdü Ölçeği}

"Müzik Dinlemeye Yönelik Güdü Ölçeği”ne ilişkin KMO katsayısı .807 ve Bartlett Testi anlamlı bulunmuştur. Ölçekte öz değeri (eigen value) 1 'den büyük olan 2 faktör bulunduğu, ölçeğin toplam varyansının (cumulative) \%45.992 olduğu ve 1 . faktördeki (müzik dinlemeye yönelik içsel güdü) 5 maddenin faktör yüklerinin .531 ile .741 arasında, 2. faktördeki (müzik din- 
lemeye yönelik dışsal güdü) 6 maddenin faktör yüklerinin .515 ile .734 arasında değiştiği saptanmıştır (Ateş ve Burak, 2019). "Müzik Dinlemeye Yönelik Güdü Ölçeği”nin Cronbach Alfa güvenirlik katsayısı $\alpha=.794$ olarak hesaplanmıştır. Bu çalışmada elde edilen verilerde ise Cronbach Alfa güvenirlik katsayısı $\alpha=.777$ olarak bulunmuştur.

\section{Şarkı Söylemeye Yönelik Güdü Ölçeği}

“Şark1 Söylemeye Yönelik Güdü Ölçeği”ne ilişkin KMO katsayısı .830 ve Bartlett Testi anlamlı bulunmuştur. Ölçekte öz değeri (eigen value) 1'den büyük olan 4 faktör bulunduğu, ölçeğin toplam varyansının (cumulative) \%67.094 olduğu ve 1. faktördeki (şarkı söylemeye yönelik içsel güdü) 5 maddenin faktör yüklerinin .510 ile .794 arasında değiştiği saptanmıştır. 2. Faktördeki (şarkı söylemekten kaynaklanan güçlükler) 5 maddenin faktör yüklerinin .561 ile .750 arasında değiştiği, 3. faktördeki (şarkı söylemeye yönelik özyeterlilik inancından kaynaklanan güdü) 3 maddenin faktör yüklerinin .723 ile .809 arasında değiştiği, 4. faktördeki (şarkı söylemeye yönelik dışsal güdü) 3 maddenin faktör yüklerinin .541 ile .801 arasında değiştiği görülmüştür (Ateş ve Burak, 2019). “Şark1 Söylemeye Yönelik Güdü Ölçeği”nin Cronbach Alfa güvenirlik katsayısı $\alpha=.871$ olarak hesaplanmıştır. Bu çalışmada elde edilen verilerde ise Cronbach Alfa güvenirlik katsayısı $\alpha=.804$ olarak bulunmuştur.

\section{Çalgı Çalmaya Yönelik Güdü Ölçeği}

"Çalgı Çalmaya Yönelik Güdü Ölçeği”ne ilişkin KMO katsayısı .829 ve Bartlett Testi anlamlı bulunmuştur. Ölçekte öz değeri (eigen value) 1'den büyük olan 3 faktör bulunduğu, ölçeğin toplam varyansının (cumulative)\%54.837 olduğu ve 1 . faktördeki (çalg1 çalmaya yönelik içsel güdü) 5 maddenin faktör yüklerinin .589 ile .782 arasında değiştiği saptanmıştır. 2.Faktördeki (çalg1 çalmaya yönelik dışsal güdü) 4 maddenin faktör yüklerinin .591 ile .787 arasında değiştiği, 3. faktördeki (çalgı çalmaktan kaynaklanan güçlükler) 5 maddenin faktör yüklerinin .559 ile .743 arasında değiştiği görülmüştür (Ateş ve Burak, 2019). "Çalg1 Çalmaya Yönelik Güdü Ö1çeği”nin Cronbach Alfa güvenirlik katsayısı $\alpha=.864$ olarak hesaplanmıştır. $\mathrm{Bu}$ çalışmada elde edilen verilerde ise Cronbach Alfa güvenirlik katsayısı $\alpha=.887$ olarak bulunmuştur.

\section{Verilerin Toplanması}

Araştırmanın gerçekleştirilebilmesi amacı ile Akdeniz Üniversitesi Sosyal ve Beşeri Bilimler Bilimsel Araştırma ve Yayın Etiği Kurulu'ndan 20- 
11-2019 tarih ve 205 karar sayısı ile uygulama için uygunluk kararı alınmıştır. Etik kurul izninden sonra, okullarda ölçeklerin uygulanması için, Antalya İl Milli Eğitim Müdürlüğünden gerekli izinler alınmıştır. Daha sonra ölçeklerin uygulanması için okullarla iletişime geçilerek ölçek uygulamalarının yapılacağ1 sınıflar belirlenmiştir. Veriler 2020 Ocak ayında bizzat araştırmacı tarafından, belirlenen okullardaki sınıflara girilip ölçekle ilgili gerekli açıklamalar yapılarak gönüllü olan katılımcılarla gerçekleştirilmiştir. Genel olarak ölçeklerin tamamının bir sınıf tarafından doldurulması yaklaşık 30 dakika sürmüştür.

\section{Verilerin Analizi}

$\mathrm{Bu}$ araştırmada öğrencilerden elde edilen verilerin analizinde kullanılmak üzere istatistik paket programlarından SPSS 23.0 paket programı kullanılmıştır. Müziğe yönelik kişisel özelliklerin ifade edilmesi için betimsel istatistikler kullanılmıştır. Verilerden elde edilen sonuçların cinsiyet, müzik dinleme, şarkı söyleme ve çalgı çalma değişkenlerine göre farklılıklarını incelemek için $t$ Testi uygulanmıştır. Bu testin uygulanması için araştırmada elde edilen verilerin normal dağılım gösterip göstermediğini tespit amacıyla öğrencilerin ölçeklerden aldıkları toplam puanlara Kolmogorov-Smirnov Testi uygulanmıştır. Büyüköztürk (2016, s.42), grup büyüklügünün 50'den küçük olmas1 durumunda Shapiro-Wilks, büyük olması durumunda KolmogorovSmirnov Testi, normalliğe uygunluğu incelemede kullanılan testlerdendir. Verilerin normal dağılıma sahip olduğu incelenmiş ve parametrik testlerin kullanılmasının uygun olduğuna karar verilmiştir. Değiş̧kenler arasında istatistiksel açıdan anlamlı bir ilişki olup olmadığını belirlemek amacıyla Pearson korelasyon katsayıları hesaplanmıştır. Etki büyüklügünün (eta-kare) hesaplanması, bulguların daha etkili ve anlaşı1ır bir şekilde yorumlanmasını sağlamaktadır (Büyüköztürk, 2016). Araştırmada etki büyüklügünün hesaplanması için kullanılan formül $\left[\eta^{2}=\mathrm{t}^{2} / \mathrm{t}^{2}+\left(\mathrm{n}_{1}+\mathrm{n}_{2}-2\right)\right]$. Etki büyüklüğü .01 (küçük), .06 (orta) ve .14 (geniş) düzeylerinde olabilir.

\section{Etik Konular}

Araştırmanın gerçekleştirilebilmesi amacı ile Akdeniz Üniversitesi Sosyal ve Beşeri Bilimler Bilimsel Araştırma ve Yayın Etiği Kurulu'ndan 20.11.2019 tarih ve 205 karar sayısı ile uygulama için uygunluk kararı alınmıştır. Araştırmanın gerçekleştiği ilkokullarda uygulama yapılabilmesi için, Akdeniz Üniversitesi aracılığı ile Antalya Milli Eğitim Müdürlüğüne başvurulmuştur. Antalya ilinde bulunan Ahmet Ferda Kahraman, Cahit Ünver ve 
Şelale İlkokullarında anket uygulanabilmesi "Milli Ĕ̆itim Bakanlığına Băğl Okul ve Kurrumlarda Yapllacak Araştırma, Yarışma ve Sosyal Etkinlik İzinlerine Yönelik İzin ve Uygulama Genelgesi" kapsamında uygun görülmüş ve Antalya İl Milli Eğitim Müdürlüğünün 10.01.2020 tarihli ve 704889 say1lı onayı ile onaylanmıştır.

\section{Bulgular}

Araştırmada öncelikle öğrencilerin müzik dinleme, şarkı söyleme ve çalgı çalmaya yönelik güdüleri ile kişisel değişkenleri arasındaki ilişkilere bak1lmıştır. Öğrencilerin, müzik dinleme $(\mathrm{t}=4.181, p=.000)$, şark1 söyleme $(\mathrm{t}=3.49, p=.001)$ ve çalg1 çalmaya yönelik ( $\mathrm{t}=3.307, p=.001)$ güdüleri, onların cinsiyetlerine göre anlamlı farkl1l1klar göstermektedir $(p<0.05)$. Kız öğrencilerin ( $\bar{x}=25.26)$ müzik dinlemeye yönelik güdüleri, erkek öğrencilere $(\bar{x}=23.15)$ göre anlamlı düzeyde yüksektir. $\eta^{2}$ değerinin .05 olmas1, etki değerinin küçük olduğunu göstermektedir. Kız öğrencilerin ( $\bar{x}=31.88)$, şarkı söylemeye yönelik güdüleri, erkek öğrencilere $(\bar{x}=29.58)$ göre anlamlı düzeyde yüksektir. $\eta^{2}$ değerinin .03 olması, etki değerinin küçük olduğunu göstermektedir. Ayrıca kız öğrencilerin ( $\overline{\mathrm{x}}=19.70)$ çalgı çalmaya yönelik güdüleri, erkek öğrencilere $(\bar{x}=17.74)$ göre daha yüksektir. $\eta^{2}$ değerinin .03 olmas1, etki değerinin küçük olduğunu göstermektedir. Yapılan pearson korelasyon analizi sonucunda öğrencilerin yaşları ile müzik dinlemeye yönelik güdüleri arasında $(\mathrm{r}=.116)$ düşük ve pozitif düzeyde anlamlı bir ilişki hesaplanmıştır $(p<0.05)$. Öğrencilerin şark1 söylemeye yönelik güdüleri ile yaşları arasında $(r=-.006)$ negatif ve düşük düzeyli bir ilişki hesaplanmıştır. Öğrencilerin çalgı çalmaya yönelik güdüleri ile yaşları arasında da $(\mathrm{r}=-.036)$ negatif ve düşük düzeyli bir ilişki hesaplanmıştır, bu ilişki anlamlı değildir $(p>0.05)$. Öğrencilerin müzik dinlemeye yönelik $(\mathrm{F}=3.036, p=.049)$ güdüleri, onların sınıf seviyelerine göre anlamlı farklı1ık göstermektedir $(p<0.05)$. $\eta^{2}$ değerinin .02 olmas1, etki değerinin küçük olduğunu göstermektedir. Tukey Testi sonucuna göre 2. sınıf öğrencilerinin müzik dinlemeye yönelik güdüleri $(\bar{x}=25.04)$, 3. sinıf öğrencilerine $(\overline{\mathrm{x}}=23.34)$ göre anlamlı düzeyde yüksek olduğu bulunmuştur.

Araştırmanın diğer sorusu öğrencilerin müzik etkinliklerine bireysel katılımları ile müzik dinleme, şarkı söyleme ve çalgı çalmaya yönelik güdüleri arasındaki ilişkiyi ortaya çıkarmayı amaçlamaktadır. Bu bağlamda öncelikle öğrencilerin bireysel müzik etkinliklerine yönelik dağılımları hesaplanmıştır. 
Tablo 1. Öğrencilerin Müziksel Etkinliklerine Yönelik Dağılımları

\begin{tabular}{lllll}
\hline Değişkenler & \multicolumn{3}{c}{ Evet } & \multicolumn{3}{c}{ Hayır } \\
\cline { 2 - 5 } & f & $\mathbf{\%}$ & f & \% \\
\hline Çalgı çalma & 143 & 40.9 & 207 & 59.1 \\
Müzik dinleme & 337 & 96.3 & 13 & 3.7 \\
Şarkı söyleme & 252 & 72 & 98 & 28 \\
Müzik topluluğuna üye olma & 54 & 15.4 & 296 & 84.6 \\
Kendine ait çalgıya sahip olma & 179 & 51.1 & 171 & 48.9 \\
Kendine ait müzikli oyuncağa sahip olma & 128 & 36.6 & 222 & 63.4 \\
Kendine ait müzik dinlemeye yarayan cihaza sahip olma & 205 & 58.6 & 145 & 41.4
\end{tabular}

Tablo 1'de görüldüğü gibi, öğrencilerin \%40.9'u çalg1 çalarken \%59.1'i çalg1 çalmamaktadır. Öğrencilerin büyük çoğunluğu olan \%96.3'ünün müzik dinlediği görülmektedir. Öğrencilerin \%72'si şark1 söylerken \%28'i şark1 söylememektedirler. Öğrencilerin \%15.4'ü müzik topluluğuna üyeyken büyük çoğunluğu olan \%84.6'sının müzik topluluğuna üye olmadıkları görülmektedir. Kendisine ait çalgısı olanlar ise \%51.1'dir. Kendisine ait müzikli oyuncağa sahip olanlar \%36.6 oranındayken olmayanların oran1 \%63.4'tür. Kendine ait müzik dinlemeye yarayan cihaza sahip olanlar \%58.6 iken kendisine ait müzik dinlemeye yarayan cihazı olmayanların ise \%41.4 olduğu görülmektedir.

Öğrencilerin bireysel müzik etkinlerine katılımları ile ölçeklerden aldıkları puanlara yapılan ilişkisel analizler sonucu, öğrencilerin, müzik dinleme ( $\mathrm{t}=-2.24, p=.025)$ ve çalg1 çalmaya yönelik $(\mathrm{t}=-6.77, p=.000)$ güdüleri, onların çalgı çalıp çalmamalarına göre anlamlı farklılıklar göstermektedir $(p<0.05)$. Çalgı çalan öğrencilerin $(\overline{\mathrm{x}}=24.93)$ müzik dinlemeye yönelik güdüleri, çalgı çalmayan öğrencilere $(\bar{x}=23.76)$ göre anlamlı düzeyde yüksektir. $\eta^{2}$ değerinin .01 olmas1, etki değerinin küçük olduğunu göstermektedir. Ayrıca çalg1 çalan öğrencilerin $(\overline{\mathrm{x}}=21.06)$ çalgı çalmaya yönelik güdüleri, çalmayan öğrencilere $(\bar{x}=17.15)$ göre anlamlı düzeyde yüksektir. $\eta^{2}$ değerinin .12 olması, etki değerinin orta derecede olduğunu göstermektedir.

Öğrencilerin müzik dinleme ( $\mathrm{t}=-5.76, p=.000)$, şarkı söyleme $(\mathrm{t}=-4.39$, $p=.000)$ ve çalg1 çalmaya yönelik ( $\mathrm{t}=-3.55, p=.000)$ güdüleri, onların müzik dinleme durumlara göre anlamlı farkl1l1klar göstermektedir $(p<0.05)$. Müzik dinleyen öğrencilerin ( $\bar{x}=24.52)$ müzik dinlemeye yönelik güdüleri, müzik dinlemeyen $(\bar{x}=17.00)$ öğrencilere göre anlamlı düzeyde yüksektir. $\eta^{2}$ değerinin .09 olmas1, etki değerinin orta derecede olduğunu göstermektedir. Müzik dinleyen öğrencilerin $(\overline{\mathrm{x}}=31.04)$ şarkı söylemeye yönelik güdüleri, müzik dinlemeyen $(\bar{x}=23.46)$ öğrencilere göre anlamlı düzeyde yüksektir. $\eta^{2}$ değerinin 
.05 olması, etki değerinin küçük olduğunu göstermektedir. Ayrıca, müzik dinleyen öğrencilerin $(\overline{\mathrm{x}}=18.95)$ çalg1 çalmaya yönelik güdüleri, müzik dinlemeyen $(\bar{x}=13.38)$ öğrencilere göre anlamlı düzeyde yüksektir. $\eta^{2}$ değerinin .03 olması, etki değerinin küçük olduğunu göstermektedir.

Öğrencilerin müzik dinleme ( $\mathrm{t}=-5.47, p=.000)$, şark1 söyleme $(\mathrm{t}=-6.81$, $p=.000)$ ve çalg1 çalmaya yönelik $(\mathrm{t}=-4.17, p=.000)$ güdüleri onların şark1 söyleyip söylememelerine göre anlamlı farkl1lıklar göstermektedir $(p<0.05)$. Şark1 söyleyen öğrencilerin ( $\bar{x}=25.08)$ müzik dinlemeye yönelik güdüleri, şark1 söylemeyen $(\bar{x}=22.06)$ öğrencilere göre anlamlı düzeyde yüksektir. $\eta^{2}$ değerinin .08 olmas1, etki değerinin orta derecede olduğunu göstermektedir. Şark1 söyleyen öğrencilerin ( $\overline{\mathrm{x}}=32.10)$ şark1 söylemeye yönelik güdüleri, şark1 söylemeyen $(\overline{\mathrm{x}}=27.32)$ öğrencilere göre anlamlı düzeyde yüksektir. $\eta^{2}$ değerinin .12 olması, etki değerinin orta derecede olduğunu göstermektedir. Ayrıca, şark1 söyleyen öğrencilerin ( $\bar{x}=19.51)$ çalg1 çalmaya yönelik güdüleri, şark1 söylemeyen $(\overline{\mathrm{x}}=16.78)$ öğrencilere göre anlamlı düzeyde yüksektir. $\eta^{2}$ değerinin .05 olmas1, etki değerinin küçük olduğunu göstermektedir.

Öğrencilerin müzik dinleme ( $\mathrm{t}=-3.52, p=.000)$, şark1 söyleme $(\mathrm{t}=-3.33$, $p=.001)$ ve çalg1 çalmaya yönelik ( $\mathrm{t}=-4.21, p=.000)$ güdüleri onların müzik topluluğuna üye olup olmamalarına göre anlamlı farkl1lıklar göstermektedir $(p<0.05)$. Müzik topluluğuna üye olan öğrencilerin $(\overline{\mathrm{x}}=26.33)$ müzik dinlemeye yönelik güdüleri, müzik topluluğuna üye olmayan $(\overline{\mathrm{x}}=23.85)$ öğrencilere göre anlamlı düzeyde yüksektir. $\eta^{2}$ değerinin .03 olması, etki değerinin küçük olduğunu göstermektedir. Müzik topluluğuna üye olan öğrencilerin ( $\bar{x}=33.33)$ şark1 söylemeye yönelik güdüleri, müzik topluluğuna üye olmayan $(\overline{\mathrm{x}}=30.29)$ öğrencilere göre anlamlı düzeyde yüksektir. $\eta^{2}$ değerinin .03 olması, etki değerinin küçük olduğunu göstermektedir. Ayrıca, müzik topluluğuna üye olanların ( $\bar{x}=21.65)$ çalgı çalmaya yönelik güdüleri, müzik topluluğuna üye olmayan $(\bar{x}=18.22)$ öğrencilere göre anlamlı düzeyde yüksektir. $\eta^{2}$ değerinin .05 olması, etki değerinin küçük olduğunu göstermektedir.

Öğrencilerin müzik dinleme ( $\mathrm{t}=-3.68, p=.000)$, şark1 söyleme $(\mathrm{t}=-2.63$, $p=.009)$ ve çalgı çalmaya yönelik ( $\mathrm{t}=-5.24, p=.007)$ güdüleri onların kendilerine ait çalgılarının olup olmamasına göre anlamlı farklılıklar göstermektedir $(p<0.05)$. Kendisine ait çalgısı olan öğrencilerin $(\overline{\mathrm{x}}=25.15)$ müzik dinlemeye yönelik güdüleri, kendisine ait çalgısı olmayan $(\overline{\mathrm{x}}=23.28)$ öğrencilere göre anlamlı düzeyde yüksektir. $\eta^{2}$ değerinin .03 olması, etki değerinin küçük olduğunu göstermektedir. Kendisine ait çalgısı olan öğrencilerin $(\overline{\mathrm{x}}=31.61)$ şark1 
söylemeye yönelik güdüleri, kendisine ait çalgısı olmayan ( $\bar{x}=29.87)$ öğrencilere göre anlamlı düzeyde yüksektir. $\eta^{2}$ değerinin .01 olmas1, etki değerinin küçük olduğunu göstermektedir. Ayrıca, kendisine ait çalgısı olan öğrencilerin $(\overline{\mathrm{x}}=20.23)$ çalgı çalmaya yönelik güdüleri, kendisine ait çalgısı olmayan $(\bar{x}=17.19)$ öğrencilere göre anlamlı düzeyde yüksektir. $\eta^{2}$ değerinin .07 olması, etki değerinin orta derecede etki değerine sahip olduğunu göstermektedir.

Araştırmanın diğer sorusu öğrencilerin evdeki müziksel ortamları ile müzik dinleme, şarkı söyleme ve çalgı çalmaya yönelik güdüleri arasındaki ilişkiyi ortaya çıkarmayı amaçlamaktadır. Bu bağlamda öncelikle öğrencilerin evdeki müziksel ortamlarına yönelik dağılımları hesaplanmıştır.

Tablo 2. Öğrencilerin Evdeki Müziksel Ortamları ve Etkinliklerine Göre Dağ1limları

\begin{tabular}{lcccc}
\hline Değişkenler & \multicolumn{2}{c}{ Evet } & \multicolumn{2}{c}{ Hayır } \\
\cline { 2 - 5 } & $\mathrm{f}$ & $\%$ & $\mathrm{f}$ & $\%$ \\
\hline Aile üyelerinden çalgı çalan olması & 133 & 38 & 217 & 62 \\
Aile üyelerinden müzik dinleyen olması & 322 & 92 & 28 & 8 \\
Aile üyelerinden şarkı söyleyen olması & 222 & 63.4 & 128 & 36.6 \\
Aile üyeleri ile çalgı çalma & 88 & 25.1 & 262 & 74.9 \\
Aile üyeleri ile müzik dinleme & 261 & 74.6 & 89 & 25.4 \\
Aile üyeleri ile şark1 söyleme & 171 & 48.9 & 179 & 51.1 \\
\hline
\end{tabular}

Tablo 2'de görüldüğü gibi öğrencilerin, aile üyelerinin \%38'i çalg1 çalarken \%62'sinin çalgı çalmadığı görülmektedir. Öğrencilerin \%92 gibi büyük çoğunluğunun aile üyeleri müzik dinlemektedirler. Katılımcıların aile üyelerinden \%63.4'ü şark1 söylerken \%36.6's1 şark1 söylememektedirler. Katılımc1ların aile üyeleri ile birlikte yaptıkları müziksel faaliyetlere bakıldığında ise \%74.9'unun aile üyeleri ile birlikte çalgı çalmadı̆̆ ile birlikte çalg1 çaldıkları görülmektedir. Öğrencilerin \%74.6's1 aile üyeleri ile birlikte müzik dinlemektedirler. Aile üyeleri ile birlikte şarkı söyleyen öğrenciler \%48.9 oranındayken söylemeyenlerin oran $1 \% 51.1$ 'dir.

Öğrencilerin evdeki müziksel ortamları ile ölçeklerden aldıkları puanlara yapılan ilişkisel analizler sonucu öğrencilerin müzik dinleme $(\mathrm{t}=-2.94$, $p=.003)$, şarkı söyleme $(\mathrm{t}=-2.53, p=.012)$ ve çalg1 çalmaya yönelik $(\mathrm{t}=-4.98$, $p=.000$ ) güdüleri onların evlerinde aile üyelerinden birinin çalgı çalıp çalmamasına göre anlamlı farklılıklar göstermektedir $(p<0.05)$. Evinde aile üyelerinden birinin çalg1 çaldığ 
güdüleri, evinde aile üyelerinden birinin çalg1 çalmadığ $(\overline{\mathrm{x}}=23.65)$ öğrencilere göre anlamlı düzeyde yüksektir. $\eta^{2}$ değerinin .02 olmas1, etki değerinin küçük olduğunu göstermektedir. Evinde aile üyelerinden birinin çalg1 çaldığ 1 öğrencilerin $(\overline{\mathrm{x}}=31.83)$ şark1 söylemeye yönelik güdüleri, evinde aile üyelerinden birinin çalgı çalmadığ $1(\bar{x}=30.10)$ öğrencilere göre anlamlı düzeyde yüksektir. $\eta^{2}$ değerinin .01 olması, etki değerinin küçük olduğunu göstermektedir. Ayrıca evinde aile üyelerinden birinin çalg1 çaldığı öğrencilerin $(\bar{x}=20.60)$ çalg1 çalmaya yönelik güdüleri, evinden aile üyelerinden birinin çalg1 çalmadığg $(\bar{x}=17.61)$ öğrencilere göre anlamlı düzeyde yüksektir. $\eta^{2}$ değerinin .06 olmas1 etki değerinin orta büyüklükte olduğunu göstermektedir.

Öğrencilerin müzik dinleme ( $\mathrm{t}=-2.83, p=.005)$, şarkı söylemeye yönelik $(\mathrm{t}=-2.54, p=.011)$ güdüleri onların evlerinde aile üyelerinden birinin müzik dinleyip dinlememesine göre anlamlı farklılıklar göstermektedir $(p<0.05)$. Evinde aile üyelerinden müzik dinleyenlerin olduğu öğrencilerin $(\overline{\mathrm{x}}=24.45)$ müzik dinlemeye yönelik güdüleri, evinde aile üyelerinden müzik dinlemeyenlerin olduğu ( $\bar{x}=21.79)$ öğrencilere göre anlamlı düzeyde yüksektir. $\eta^{2}$ değerinin .02 olması, etki değerinin küçük olduğunu göstermektedir. Ayrıca, evinde aile üyelerinden müzik dinleyenlerin olduğu öğrencilerin $(\overline{\mathrm{x}}=31.01)$ şark1 söylemeye yönelik güdüleri, evinde aile üyelerinden müzik dinlemeyenlerin olduğu $(\bar{x}=27.89)$ öğrencilere göre anlamlı düzeyde yüksektir. $\eta^{2}$ değerinin .01 olmas1, etki değerinin küçük olduğunu göstermektedir.

Öğrencilerin müzik dinleme ( $\mathrm{t}=-2.83, p=.005)$, şark1 söylemeye yönelik $(\mathrm{t}=-2.54, p=.011)$ güdüleri onların evlerinde aile üyelerinden birinin şarkı söyleyip söylememesine göre anlamlı farkl11ıklar göstermektedir $(p<0.05)$. Evinde aile üyelerinden şark1 söyleyenlerin olduğu öğrencilerin $(\overline{\mathrm{x}}=24.93)$ müzik dinlemeye yönelik güdüleri, evinde aile üyelerinden şarkı söyleyenlerin olmadığ $1(\bar{x}=23.03)$ öğrencilere göre anlamlı düzeyde yüksektir. $\eta^{2}$ değerinin .03 olmas1, etki değerinin küçük olduğunu göstermektedir. Ayrıca evinde aile üyelerinden şark1 söyleyenlerin olduğu öğrencilerin ( $\bar{x}=31.41)$ şark1 söylemeye yönelik güdüleri, evinde aile üyelerinden şarkı söyleyenlerin olmadığ $(\bar{x}=26.93)$ öğrencilere göre anlamlı düzeyde yüksektir. $\eta^{2}$ değerinin .01 olması etki değerinin küçük olduğunu göstermektedir. Öğrencilerin müzik dinleme $(\mathrm{t}=-3.64, p=.000)$, şark1 söyleme $(\mathrm{t}=-4.80, p=.000)$ ve çalg1 çalmaya yönelik $(\mathrm{t}=-6.25, p=.000)$ güdüleri, onların evlerinde aile üyeleri ile birlikte çalgı çalıp çalmamalarına göre anlamlı farklılıklar göstermektedir $(p<0.05)$. Evlerinde aile üyeleri ile birlikte çalgı çalan öğrencilerin $(\overline{\mathrm{x}}=25.83)$ müzik dinlemeye 
yönelik güdüleri, evlerinde aile üyeleri ile birlikte çalgı çalmayan $(\overline{\mathrm{x}}=23.70)$ öğrencilere göre anlamlı düzeyde yüksektir. $\eta^{2}$ değerinin .03 olması, etki değerinin küçük olduğunu göstermektedir. Evlerinde aile üyeleri ile birlikte çalg1 çalan öğrencilerin ( $\bar{x}=33.45)$ şarkı söylemeye yönelik güdüleri, evlerinde aile üyeleri ile birlikte çalgı çalmayan $(\overline{\mathrm{x}}=29.85)$ öğrencilere göre anlamlı düzeyde yüksektir. $\eta^{2}$ değerinin .06 olması, etki değerinin orta büyüklükte olduğunu göstermektedir. Ayrıca, evlerinde aile üyeleri ile birlikte çalgı çalan öğrencilerin $(\overline{\mathrm{x}}=21.83)$ çalg1 çalmaya yönelik güdüleri, evlerinde aile üyeleri ile birlikte çalgı çalmayan ( $\overline{\mathrm{x}}=17.71)$ öğrencilere göre anlamlı düzeyde yüksektir. $\eta^{2}$ değerinin .10 olması, etki değerinin orta büyüklükte olduğunu göstermektedir.

Öğrencilerin müzik dinleme $(\mathrm{t}=-4.97, p=.000)$, şark1 söyleme $(\mathrm{t}=-4.78$, $p=.000)$ ve çalg1 çalmaya yönelik ( $\mathrm{t}=-4.06, p=.000)$ güdüleri, onların evlerinde aile üyeleri ile müzik dinleyip dinlememelerine göre anlamlı farklılıklar göstermektedir $(p<0.05)$. Evlerinde aile üyeleri ile müzik dinleyen öğrencilerin $(\overline{\mathrm{x}}=24.96)$ müzik dinlemeye yönelik güdüleri, evlerinde aile üyeleri ile birlikte müzik dinlemeyen ( $\overline{\mathrm{x}}=22.11)$ öğrencilere göre anlamlı düzeyde yüksektir. $\eta^{2}$ değerinin .06 olması, etki değerinin orta büyüklükte olduğunu göstermektedir. Evlerinde aile üyeleri ile birlikte müzik dinleyen öğrencilerin $(\overline{\mathrm{x}}=31.67)$ şarkı söylemeye yönelik güdüleri, evlerinde aile üyeleri ile birlikte müzik dinlemeyen $(\bar{x}=28.10)$ öğrencilere göre anlamlı düzeyde yüksektir. $\eta^{2}$ değerinin .06 olması, etki değerinin orta büyüklükte olduğunu göstermektedir. Ayrıca, evlerinde aile üyeleri ile birlikte müzik dinleyen öğrencilerin $(\bar{x}=19.44)$ çalg1 çalmaya yönelik güdüleri, evlerinde aile üyeleri ile birlikte müzik dinlemeyen $(\bar{x}=16.70)$ öğrencilere göre anlamlı düzeyde yüksektir. $\eta^{2}$ değerinin .04 olması, etki değerinin küçük olduğunu göstermektedir.

Öğrencilerin müzik dinleme ( $\mathrm{t}=-5.67, p=.000)$, şark1 söyleme $(\mathrm{t}=-6.33$, $p=.000)$ ve çalgı çalmaya yönelik ( $\mathrm{t}=-4.41, p=.000)$ güdüleri, onların evlerinde aile üyeleri ile şarkı söyleyip söylememelerine göre anlamlı farklılıklar göstermektedir $(p<0.05)$. Evlerinde aile üyeleri ile şarkı söyleyen öğrencilerin $(\overline{\mathrm{x}}=25.67)$ müzik dinlemeye yönelik güdüleri, evlerinde aile üyeleri ile birlikte müzik dinlemeyen $(\overline{\mathrm{x}}=22.87)$ öğrencilere göre anlamlı düzeyde yüksektir. $\eta^{2}$ değerinin .08 olmas1, etki değerinin orta büyüklükte olduğunu göstermektedir. Evlerinde aile üyeleri ile şark1 söyleyen öğrencilerin $(\overline{\mathrm{x}}=32.82)$ şark1 söylemeye yönelik güdüleri, evlerinde aile üyeleri ile birlikte şarkı söylemeyen 
$(\overline{\mathrm{x}}=28.79)$ öğrencilere göre anlamlı düzeyde yüksektir. $\eta^{2}$ değerinin .10 olması, etki değerinin orta büyüklükte olduğunu göstermektedir. Ayrıca, evlerinde aile üyeleri ile şarkı söyleyen öğrencilerin $(\overline{\mathrm{x}}=20.07)$ çalgı çalmaya yönelik güdüleri, evlerinde aile üyeleri ile şarkı söylemeyen $(\bar{x}=17.78)$ öğrencilere göre anlamlı düzeyde yüksektir. $\eta^{2}$ değerinin .05 olması, etki değerinin küçük olduğunu göstermektedir.

Araştırmanın diğer sorusu öğrencilerin öğretmenlerinin derslerde müziksel etkinlikleri gerçekleştirme durumları ile müzik dinleme, şarkı söyleme ve çalgı çalmaya yönelik güdüleri arasındaki ilişkiyi ortaya çıkarmayı amaçlamaktadır. Bu bağlamda öncelikle öğrencilerin öğretmenlerinin derslerde müzik etkinliklerini gerçekleştirme dağılımları saptanmıştır.

Tablo 3. Öğrencilerin Öğretmenlerinin Derslerdeki Müziksel Etkinliklerine Göre Dağglımları

\begin{tabular}{lllll}
\hline Değişkenler & \multicolumn{2}{c}{ Evet } & \multicolumn{2}{c}{ Hayır } \\
\cline { 2 - 5 } & f & $\mathbf{\%}$ & $\mathbf{f}$ & $\mathbf{\%}$ \\
\hline Derslerde öğretmenin çalgı çalması & 113 & 32.3 & 237 & 67.7 \\
Derslerde öğretmenin müzik dinletmesi & 252 & 72 & 98 & 28 \\
Derslerde öğretmenin şarkı söylemesi & 174 & 49.7 & 176 & 50.3 \\
Derslerde öğretmen ile çalgı çalma & 68 & 19.4 & 282 & 80.6 \\
Derslerde öğretmen ile müzik dinleme & 182 & 52 & 168 & 48 \\
Derslerde öğretmen ile şarkı söyleme & 131 & 37.4 & 219 & 62.6 \\
Derslerde öğretmenin öğrencileri şarkı söylemek için zorla tah- & 261 & 74.6 & 89 & 25.4 \\
taya kaldırması & & & & \\
\hline
\end{tabular}

Tablo 3 incelendiğinde, derslerde öğretmeni çalgı çalan öğrencilerin oranı \%32.3, çalmayanların oranı ise \%67'dir. Öğrencilerin \%72'sinin öğretmeninin derslerde müzik dinlettiği görülmektedir. Öğrencilerin \%49.7'sinin öğretmeni derste şarkı söylerken \%50.3'ünün öğretmeni derslerde şarkı söylememektedir. Derslerde öğretmeni ile birlikte çalgı çalanlar \%19.4 oranındayken, çalmayanların oranı \%80.6 gibi büyük çoğunluğu oluşturmaktadır. Derslerde öğretmeni ile müzik dinleyenler $\% 52$ oranındayken dinlemeyenlerin oranının \%48 olduğu görülmektedir. Derslerde öğretmeni ile birlikte şarkı söyleyen öğrenciler \%37.4 oranındayken, söylemeyenlerin oranı \%62.6'dır. Öğrencilerin \%74.6'sının öğretmeni, derslerde öğrencilerini şarkı söylemek için zorla tahtaya kaldırmaktadır.

Yapılan ilişkisel analizler sonucunda öğrencilerin müzik dinleme $(\mathrm{t}=2.97, p=.003)$, şark1 söyleme ( $\mathrm{t}=-2.24, p=.026)$ ve çalg1 çalmaya yönelik $(\mathrm{t}=-2.71, p=.007)$ güdüleri, onların derslerde öğretmenlerinin çalgı çalıp çal- 
mamasına göre anlamlı farklılıklar göstermektedir $(p<0.05)$. Derslerde öğretmeni çalgı çalan öğrencilerin ( $\bar{x}=25.34)$ müzik dinlemeye yönelik güdüleri, derslerde öğretmeni çalg1 çalmayan $(\overline{\mathrm{x}}=23.71)$ öğrencilere göre anlamlı düzeyde yüksektir. $\eta^{2}$ değerinin .02 olmas1, etki değerinin küçük olduğunu göstermektedir. Derslerde öğretmeni çalgı çalan öğrencilerin $(\bar{x}=31.84)$ şarkı söylemeye yönelik güdüleri, derslerde öğretmeni çalg1 çalmayan $(\bar{x}=30.24)$ öğrencilere göre anlamlı düzeyde yüksektir. $\eta^{2}$ değerinin .01 olması, etki değerinin küçük olduğunu göstermektedir. Ayrıca, derslerde öğretmeni çalgı çalan öğrencilerin $(\bar{x}=19.92)$ çalg1 çalmaya yönelik güdüleri, derslerde öğretmeni çalg1 çalmayan $(\bar{x}=18.19)$ öğrencilere göre anlamlı düzeyde yüksektir. $\eta^{2}$ değerinin .02 olmas1, etki değerinin küçük olduğunu göstermektedir. Öğrencilerin müzik dinleme $(\mathrm{t}=-1.26, p=.207)$, şark1 söyleme $(\mathrm{t}=-.029, p=.977)$ ve çalg1 çalmaya yönelik ( $\mathrm{t}=-.339, p=.735)$ güdüleri, onların öğretmenlerinin derslerde müzik dinletip dinletmemesine göre anlamlı farkl1lık göstermemektedir $(p>0.05)$.

Öğrencilerin müzik dinlemeye yönelik ( $\mathrm{t}=-2.56, p=.011)$ güdüleri, onların derslerde öğretmenlerinin şark1 söyleyip söylememelerine göre anlamlı farkl11ık göstermektedir $(p<0.05)$. Derslerde öğretmeni şark1 söyleyen öğrencilerin $(\overline{\mathrm{x}}=24.90)$ müzik dinlemeye yönelik güdüleri, derslerde öğretmeni şark1 söylemeyen $(\bar{x}=23.59)$ öğrencilere göre anlamlı düzeyde yüksektir. $\eta^{2}$ değerinin .02 olmas1, etki değerinin küçük olduğunu göstermektedir. Öğrencilerin çalgı çalmaya yönelik ( $\mathrm{t}=-2.59, p=.010)$ güdüleri, onların derslerde öğretmenleri ile çalgı çalıp çalmamalarına göre anlamlı farklılık göstermektedir $(p<0.05)$. Derslerde öğretmenleri ile birlikte çalg1 çalan öğrencilerin $(\overline{\mathrm{x}}=20.32)$ çalg1 çalmaya yönelik güdüleri, derslerde öğretmenleri ile birlikte çalg1 çalmayan ( $\bar{x}=18.37)$ öğrencilere göre anlamlı düzeyde yüksektir. $\eta^{2}$ değerinin .01 olmas1, etki değerinin küçük olduğunu göstermektedir.

Öğrencilerin müzik dinlemeye yönelik ( $\mathrm{t}=-2.38, p=.018)$ güdüleri, onların derslerde öğretmenleri ile birlikte müzik dinleyip dinlememelerine göre anlamlı farklılık göstermektedir $(p<0.05)$. Derslerde öğretmenleri ile müzik dinleyen öğrencilerin ( $\bar{x}=24.82)$ müzik dinlemeye yönelik güdüleri, dinlemeyen $(\overline{\mathrm{x}}=23.60)$ öğrencilere göre anlamlı düzeyde yüksektir. $\eta^{2}$ değerinin .02 olmas1, etki değerinin küçük olduğunu göstermektedir. Öğrencilerin müzik dinlemeye yönelik ( $\mathrm{t}=-2.25, p=.025)$ güdüleri, onların derslerde öğretmenleri ile şark1 söyleyip söylememelerine göre anlamlı farklılık göstermektedir $(p<0.05)$. Derslerde öğretmenleri ile birlikte şark1 söyleyen öğrencilerin 
$(\overline{\mathrm{x}}=24.98)$ müzik dinlemeye yönelik güdüleri, söylemeyen $(\overline{\mathrm{x}}=23.79)$ öğrencilere göre anlamlı düzeyde yüksektir. $\eta^{2}$ değerinin .01 olması, etki değerinin küçük olduğunu göstermektedir. Öğrencilerin müzik dinlemeye yönelik $(\mathrm{t}=2.48, \mathrm{p}=.013)$ güdüleri, onların derslerde öğretmenlerin öğrencilerini şarkı söyleyip söylemek için zorla tahtaya kaldırıp kaldırmamasına göre anlamlı farkl11ık göstermektedir $(p<0.05)$. Derste öğretmeni tarafından şarkı söylemek için zorla tahtaya kaldıran öğrencilerin $(\overline{\mathrm{x}}=23.15)$ müzik dinlemeye yönelik güdüleri, kaldırılmayan $(\overline{\mathrm{x}}=24.61)$ öğrencilere göre anlamlı düzeyde yüksektir. $\eta^{2}$ değerinin .01 olması, etki değerinin küçük olduğunu göstermektedir.

\section{Tartıșma}

Öğrencilerin bireysel müzik etkinliklerini ne kadar gerçekleştirdiklerine yönelik dağılımları incelendiğinde, onların büyük çoğunluğunun müzik dinleme ve şarkı söyleme etkinliklerinde bulunduğu anlaşılmıştır. Bununla birlikte çalgı çalan öğrencilerin oranının çalmayan öğrencilere göre daha düşük olduğu saptanmıştır. Ayrıca müzik topluluğuna üye olan öğrenciler de olmayan öğrencilere göre azınlıkta kalmaktadır. Müzik dinlemek ve şarkı söylemek, öğrenciler açısından diğer müziksel etkinliklere kıyasla daha kolaylıkla gerçekleştirebilecekleri, daha az maddi olanak gerektiren ve daha az çabada bulunulması gereken etkinlikler olarak görülebilir. Bununla birlikte çalg1 çalmak ve müzik topluluğuna üye olmak gibi müziksel etkinlikler okul ve okul dışındaki sosyal ve müziksel ortamın daha yeterli ve donanımlı olmasını gerektirmektedir. Yazıcı (2012) ilköğretim okullarında yapmış olduğu çalışmasında müzik öğretimi için gerekli olan alt yapının yetersiz olduğu sonucuna ulaşmıştır. Öğretmenler, okullarda müzik dersliğinin bulunmadığını belirtmiş ve bu durum müzik dersi programının uygulanabilirliğini olumsuz yönde etkileyen bir faktör olarak görülmüştür. Tanyeli (2007) ise okullardaki araç-gereç eksikliği ve sınıfların kalabalık olmasının öğretmenlerin müzik etkinliklerini uygulamalarında sorun oluşturduğunu belirtmiş̧ir. Dolayısıyla müzik dersi programının uygulanabilirliğinin olumsuz etkilenmesi ve öğretmenin yapacağ1 müziksel etkinliklerin aksaması çalg1 eğitimini de aksatabileceğinden öğrencilerin çalgı çalma durumlarını da etkileyebileceği düşünülmektedir. $\mathrm{Bu}$ sebeple birebir ilgi ve araç-gereç gerektiren çalgı eğitiminin gerçekleşmesini ve verim alınmasını zorlaştırabilir.

Öğrencilerin evdeki müziksel ortamlarında müzik etkinliklerini ne kadar gerçekleştirdiklerine yönelik dağılımları incelendiğinde, ailelerinin büyük 
çoğunluğunun müzik dinleme ve şark1 söyleme etkinliklerinde bulunduğu görülmüştür. Bununla birlikte ailesinde çalg1 çalanların olduğu öğrencilerin oranı çalmayan öğrencilere göre daha düşük olduğu saptanmıştır. Ayrıca, ailesi ile birlikte çalgı çalan öğrenciler de çalmayan öğrencilere göre azınlıkta kalmaktadır. Özmenteş (2012) evdeki müziksel ortamın geliştirilmesinin öğrencilerin müzik derslerine ilişkin tutumlarının arttırılmasında önemli bir rol oynadığını bildirmiştir. Ayrıca müzik dinleme ve şarkı söyleme etkinliklerinin ekonomik olarak aileleri yıpratmayacak etkinlikler olmasından dolayı aileler tarafından bu tür etkinliklerin diğer müziksel etkinliklere kıyasla daha çok yapıldığını bildirmiştir. Buradan hareketle, ebeveynlerin evde yaptıkları müziksel etkinliklerin çocukların bireysel müziksel etkinliklerini de etkileyeceği düşünülebilir. Benzer biçimde Sichivitsa (2007) araştırmasında ebeveynlerin çocuklarının müziksel çabalarını desteklemelerinin çocukların müziğe olan ilgisini ve tutumunu arttırdığını belirtmiştir. Bu bağlamda, çocuğun evdeki müziksel ortamı ne kadar iyileşirse müziğe olan ilgisi de artacak ve müziksel etkinlikleri yapma/katılma durumları iyileşecektir.

Öğrencilerin öğretmenlerinin derslerde müziksel etkinlikleri ne kadar gerçekleştirdiklerine yönelik dağglımları incelendiğinde, öğretmenlerin büyük çoğunluğunun derslerde öğrencilerine müzik dinletme etkinliklerinde bulundukları anlaşılmıştır. Bununla birlikte öğretmenleri çalgı çalan öğrencilerin oranı öğretmenleri çalgı çalmayan öğrencilere göre daha düşüktür. Ayrıca, öğretmenleri ile birlikte çalg1 çalan öğrenciler de çalmayan öğrencilere göre azınlıkta kalmaktadır. Bunun yanında, öğrencilerin büyük çoğunluğunun öğretmeni, öğrencilerini derslerde şarkı söylemek için zorla tahtaya kaldırmaktadır. Daha önce de değinildiği gibi öğretmenler daha az çaba gerektiren müzik dinleme ve şarkı söyleme gibi etkinliklerde bulunmaktadırlar. Kendilerinin müziğe yönelik yetersizliklerini belirttikleri araştırmalar alanyazında mevcuttur. Kılıç (2009) sınıf öğretmenlerinin lisansta aldıkları müzik öğretimi dersini sınıfta az yansitabildikleri ve lisanstaki bu dersin yetersiz olduğu sonucuna ulaşmıştır. Kurtuldu (2009) sınıf öğretmeni adaylarının müzik öğretimi derslerinde müziğin nasıl öğretileceğine ilişkin bilgiler alırken farklı yöntemler hakkında bilgilendirilmediklerini belirtmiştir. Göğüş (2008) sınıf öğretmenlerinin müzik derslerinde kendilerini verimli bulmadıklarını, bu durumu da yeterli birikimleri olmamasına ve fiziksel olanakların yetersiz oluşuna bağladıkları sonucuna ulaşmıştır. Belirtilen araştırmalara göre sınıf öğretmenlerinin müzik eğitiminde kendilerini yetersiz hissetmeleri sonucu s1- 
nıfta etkili müzik etkinliklerini gerçekleştirme olanakları azalmaktadır. Bu sebeple öğretmenin çalg1 çalma ve öğrencileri ile müziksel etkinlikler gerçekleştirmesinin pek mümkün olamayacağı düşünülmektedir. Çevik (2011) sınıf öğretmeni adaylarının müzik öğretimine ilişkin özyeterlilik inançlarının güçlü olduğu sonucuna ulaşmış, fakat müzik öğretiminde etkili bir öğrenme ortamı oluşturmak için daha fazla çaba harcamaları gerektiğini belirtmiştir. Özyeterlilik inancı, bireyin güdülerini ve dolayısıyla davranışlarını düzenlemektedir (Atabek ve Burak, 2019b).

Barış ve Özata (2009), sınıf öğretmenlerinin kendilerini seslerini kullanabilecek yeterlilikte bulmadıklarını bildirmiştir. Öğretmen adayları ise, müzik öğretimindeki başarı-başarısızlıklarını öğretmenlik becerilerine yüklemektedirler. Öğretmen adaylarının sahip oldukları öğretmenlik becerisine ilişkin inançlarının müzik öğretimindeki uygulamalarda kendilerine olan güvenlerini ve doğal olarak müzik öğretimindeki başarı-başarısızlıklarına yönelik inançlarını etkilediği görülmüştür (Saka ve Burak, 2016). Bu bağlamda, öğretmenler müzik dersini planlamadıkları için ve fiziksel olanakların yetersizliğinden kaynaklı sınıf içi müziksel etkinliklere yer vermedikleri düşünülebilir.

Araştırmada, kız öğrencilerin müzik dinleme, şark1 söyleme ve çalg1 çalmaya yönelik güdülerinin erkek öğrencilere göre anlamlı derecede yüksek olduğu bulunmuştur. Bu bulgu, kız öğrencilerin müziğe, erkek öğrencilerden daha fazla değer verdiklerini bildiren McPherson ve arkadaşlarının (2015) araştırma sonuçları ile benzerlik göstermektedir. Müziğe yönelik güdüden farklı olarak müziğe yönelik diğer duyuşsal özelliklerin kız öğrenciler lehine anlamlı farklılıklar gösterdiği başka araştırma sonuçlarına da rastlanmaktadır. $\mathrm{Bu}$ araştırmalara göre kız öğrencilerin müzik dersine yönelik tutumları erkek öğrencilere göre daha yüksektir (Nacakc1, 2006; Otacıŏlu, 2007; Özmenteş, 2012). Bununla birlikte başarıya yönelik olarak güdülenmenin de kızlarda erkek öğrencilere göre daha yüksek olduğu görülmektedir. Çelik (2006), ilkokul öğrencileri ile yaptığı çalışmada kız öğrencilerin başarı güdülerinin erkek öğrencilere göre daha yüksek olduğu sonucuna ulaşmıştır. Ellez (2004) ise çalışmasında, kız öğrencilerin gayret etme ve katılım boyutlarındaki güdü puanlarının erkek öğrencilere göre daha yüksek olduğunu bildirmiştir. Kız öğrencilerin müziğe yönelik güdülerinin daha yüksek olması, onların duyuşsal gelişimlerinden kaynaklı daha erken olgunlaşmaları sonucunda sorumluluk sahibi olmalarından dolayı olabilir. 
Öğrencilerin sınıfları ile müzik dinleme, şarkı söyleme ve çalgı çalmaya yönelik güdüleri arasındaki ilişkiler incelenmiş olup öğrencilerin yaşları ile müzik dinlemeye yönelik güdüleri arasında anlamlı ilişki olduğu saptanmıştır. Öğrencilerin sınıfları ile müzik dinleme, şarkı söyleme ve çalg1 çalmaya yönelik güdüleri arasındaki ilişki incelenmiş olup 2. sınıf öğrencilerinin müzik dinlemeye yönelik güdüleri ile 3 . sınıf öğrencilerine göre anlamlı derecede yüksektir. Bu sonuç Otacıoğlu (2007)'nun araştırma sonucu ile benzerlik göstermektedir. Otacıoğlu (2007) araştırmasında, öğrencilerin sınıf seviyeleri ve yaşları büyüdükçe, sanat derslerine verdikleri önemin ve ilginin azaldığı sonucuna ulaşmıştır. Kocabaş ve Selçioğlu (2006) ise, dördüncü ve beşinci sınıf öğrencilerinin müzik dersinin gerçekleşme düzeyine ilişkin görüşleri arasında anlamlı bir farklılık olduğu ve müzik dersinin dördüncü sınıflarda daha anlamlı gerçekleştiği sonucuna ulaşmışlardır.

Araştırma sonuçlarından öğrencilerin bireysel müzik etkinlikleri incelendiğinde; çalg1 çalan, müzik dinleyen, şark1 söyleyen, müzik topluluğuna üye olan, çalgısı olan ve evinde müzikli oyuncağı bulunan öğrencilerin müzik dinleme, şarkı söyleme ve çalgı çalmaya yönelik güdülerinin diğer öğrencilere göre anlamlı düzeyde yüksek olduğu sonucuna ulaşılmıştır. Bu bulgudan yola çıkarak öğrencilerin müziğe yönelik daha fazla güdülenmeleri için daha çok bireysel müzik etkinliklerinde bulunmaları, sosyal çevrelerinden arkadaş, öğretmen ve ailesinden bu etkinliklerde bulunmaları için destek almaları önemlidir. Bireyde doğuştan getirilen müziksel becerilerin ortaya çıkıp gelişebilmesi için bireyin belli müziksel yaşantılarla etkileşim halinde olması gerekmektedir. Bireyde bulunan ve kalıtım yoluyla nesilden nesile aktarılan müziksel beceriler, gerekli müziksel çevre ile etkileşime girilmediği sürece müziksel davranışlara dönüşemez (Özdemir ve Yıldız, 2010). Bu duruma sebebiyet vermemek için birey çevresinde ne kadar çok müziksel ortama maruz bırakılırsa o derece müziğe yönelik güdüsü artacaktır.

Araştırmadan elde edilen bulgulara göre, evinde aile üyelerinden birinin çalg1 çaldığ 1 ve aile üyeleri ile birlikte çalgı çalan, müzik dinleyen ve şarkı söyleyen öğrencilerin; müzik dinleme, şarkı söyleme ve çalg1 çalmaya yönelik güdüleri diğerlerine göre anlamlı düzeyde yüksektir. Öğrencilerin evdeki müziksel ortamları ile müziğe yönelik güdüleri arasında ilişki olduğu anlaşılmaktadır. Müziğe ilgi duyan bir ailede bulunan ve aile üyeleri ile birlikte müziksel etkinlikler yapan öğrencilerin müziğe yönelik güdülerinin yükseldiği görülmektedir. Bu nedenle aile, çocuğu için evde müziksel etkinlikler için ne kadar 
çok olanak sağlarsa ve buna aile üyeleri de katılırsa çocuğun müziğe yönelik güdülerinin artacağı düşünülebilir. Kebapc1 (2019) yaptı̆̆ çalışmasında, öğrencilerin aile üyelerinden müzikle ilgilenen biri olması ve aile üyeleri ile birlikte düzenli olarak müzik dinleyen öğrencilerin evdeki müziksel ortam ölçeğinden daha çok puan aldıkları sonucuna ulaşmıştır. Benzer biçimde Brand (1986) ise, evdeki müziksel ortam değişkenlerinin öğrencilerin müzikal başarılarını arttığını ve ebeveynlerin müziğe katılımlarının çocukların müziğe karşı tutumlarını etkilediğini belirtmiştir. Özmenteş (2012), öğrencilerin evlerinde müzik dinlemesi ve şark1 söylenmesi faktörleri ile müziğe yönelik tutumları arasında ilişki olduğu sonuca ulaşmıştır. Youm (2013), erken çocuklukta evdeki müzik eğitimi ve aile üyelerinin hedeflerini, isteklerini araştırmıştır. Ailedeki birincil müziksel uygulamaların şarkı söylemek, müzik dinlemek, çalgı çalmak olduğu bulgusu ortaya çıkmış ve katılımcılar, sadece çocukları için değil kendileri için de müzik becerileri ve bilgisi öğrenme arzusunda olduklarını belirtmişlerdir. Bu bulgudan hareketle çocukların müziğe yönelik güdülenmelerinde ebeveynlerinin müzik eğitiminin almalarının da gerekli olduğu anlaşılmıştır.

Araştırmadan elde edilen bulgulara göre, derslerde öğretmeni çalgı çalan ve şark1 söyleyen öğrencilerin; müzik dinleme, şarkı söyleme ve çalg1 çalmaya yönelik güdülerinin anlamlı düzeyde yüksek olduğu sonucuna ulaşılmıştır. Bu sonuç, Sichivitsa (2007)'ın araştırmasını destekler niteliktedir. Sichivitsa (2007) çalışmasında öğrencilerinin hem sosyal hem de akademik ihtiyaçlarına hitap eden öğretmenlerin, onların müziğe verdikleri değeri ve müzik etkinliklerine devam etme güdülerini arttırdıklarını bildirmektedir. Öğretmenlerin öğrencileri için rol model olarak daha sıkl1kla müziksel etkinliklere yer vermeleri onların müziğe karşı daha fazla güdülenmelerini sağlayabilir. Kocabaş (2000) sınıf öğretmenleri ile yaptığı çalışmada, lisans döneminde aldıkları müzik dersinin, müzik öğretimini sağlamada yeterli olmadığını belirtmiştir. Müzik öğretim yöntem ve tekniklerine ilişkin aldıkları hizmet içi eğitimin de yeterli olmadığını vurgulamışlardır. Buradan hareketle, sınıf öğretmenlerine verilecek hizmet içi eğitimin içeriğinin ve etkililiğinin iyileştirilmesi gerekebilir. Özmenteş (2013), öğretmenlerin ve öğrencilerin güdüsünü etkileyen faktörlerin başında öğretmen-öğrenci iletişiminin sağlıklı olması gerektiğini belirtmiştir. Öğrencilerde, öğrenme şekli ve kişisel özellikler bakımından farklılık olabilmekte, bununla birlikte öğrenciler farklı şekillerde güdülenmektedirler. Dolayısıyla, öğretmenler, öğrencilerine müzik adına farkı şekil- 
lerde rol model olabilir. Bazı öğrenciler öğretmeninin çalgı çalmasıyla güdülenirken bazı öğrenciler de öğretmeninin şarkı söylemesiyle güdülenebilir. Buradan hareketle, öğretmenlerin sınıflarında daha sıklıkla müziksel etkinlik gerçekleştirmeleri, öğrencilerini müziksel olarak güdülemelerine olanak sağlayacaktır. Gerçekleştirilecek bu etkinliklerin eğlenceli ve ilginç olması güdünün oluşmasına ve artmasına da katkı sağlayacaktır (Atabek ve Burak, 2019a). Öte yandan, güdünün oluşmu ve güçlenişi ülkelere ve kültürlere göre farklılık göstermektedir (Atabek, 2019). Dolayısı ile ilkokul öğrencilerinin müziğe yönelik güdülerinin artırılabilmesi için, Türkiye'nin kültürel özelliklerinin de hesaba katıldığı öğretim programı, strateji ve etkinliklere gereksinim duyulmaktadir.

\section{Sonuç}

Araştırma sonucunda, ilkokul öğrencilerinin bireysel olarak müzik etkinliklerini gerçekleştirmeleri, evdeki müziksel ortamlarının niteliği ve öğretmenlerinin sınıf içi müziksel etkinlikleri gerçekleştirme durumlarının, onların müziğe yönelik güdülenmeleri açısından önemli etkenler olduğu anlaşılmaktadır. Bu bağlamda, öğrencilerin müziğe yönelik güdülenmelerinin sağlanabilmesi için onların, çalgı çalma, müzik dinleme vb. gibi müziksel etkinlikleri hem ders içinde hem ders dışında daha fazla gerçekleştirebilmeleri için ortam hazırlanmalı, sınıf öğretmenlerinin müzik konusundaki yeterlilik ve donanımları üzerinde önemle durulan bir konu olmalıdır.

\section{Kaynakça}

Açıkgöz, K. Ü. (2005). Etkili öğrenme ve ögrretme. Ankara: Eğitim Dünyası Yayınları. Akbaba, S. (2006). Eğitimde motivasyon. Atatürk Üniversitesi Kazım Karabekir Ĕgitim Fakültesi Dergisi, 13, 343-361.

Atabek, O. (2013). An exploratory study on the use of Facebook by pre-service teachers in Turkey and the U.S.A: A mixed method design. Yayımlanmamıs doktora tezi, Orta Doğu Teknik Üniversitesi Fen Bilimleri Enstitüsü. http://etd.lib.metu.edu.tr/upload/12616814/index.pdf

Atabek, O. (2019). Personal differences and social networking: A comparison of two countries. Educational Policy Analysis and Strategic Research, 14(4), 167189.

Doi: $10.29329 /$ epasr.2019.220.10

Atabek, O. (2020). Associations between emotional states, self-efficacy for and attitude towards using educational technology. International Journal of Progressive Education, 16(2), 175-194.

Doi: $10.29329 /$ ijpe.2020.241.12

Atabek, O. ve Burak, S. (2019a). Designing a teacher's handbook: Perspectives of pre-service elementary teachers regarding activities and songs. International Education Studies, 12(11), 67-79. 
Doi: $10.5539 /$ ies.v12n11p67

Atabek, O. ve Burak, S. (2019b). Müzik öğretmeni adaylarının eğitim teknolojisine yönelik özyeterlilik ve tutumları. Akdeniz Eğitim Araştırmaları Dergisi, 13(29), 444-464.

Doi: 10.29329/mjer.2019.210.23

Atabek, O., Orhon, G. ve Burak, S. (2019). Psychological well-being of prospective teachers: the case of pedagogical formation students. International Online Journal of Education and Teaching, 6(4), 799-814. https://iojet.org/index.php/IOJET/article/view/543_

Ateş, G. ve Burak, S. (2019, Ekim). Müzik dinleme, şarkı söyleme ve çalgı çalmaya yönelik güdü ölçeklerinin geliştirilmesi. 18. Uluslararası Sınıf Öğretmenliği Eğitimi Sempozyumu'nda sunulan bildiri, Antalya.

Barış, D. A. ve Özata, E. (2009). Sınıf öğretmenliği anabilim dalında alınan müzikmüzik öğretimi derslerinin öğretmenlik uygulamalarındaki yansımaları. Mehmet Akif Ersoy Üniversitesi Ĕ̈itim Fakültesi Dergisi, 18, 27-42.

Bilen, S. (1995). Işsbirlikli öğrenmenin müzik öğretimi ve güdüsel süreçler üzerindeki etkileri. Yayımlanmamış doktora tezi, Dokuz Eylül Üniversitesi Eğitim Bilimleri Enstitüsü.

Brand, M. (1986). Relationship between home musical environment and selected musical attributes of second-grade children. Journal of Research in Music Education, 34(2), 111-120.

Burak, S. ve Atabek, O. (2019). Association of career satisfaction with stress and depression: the case of preservice music teachers. Journal of Education and Learning, 8(5), 125-135.

Doi: $10.5539 /$ jel.v8n5p125

Büyüköztürk, Ş. (2016). Veri analizi el kitabı. Ankara: Pegem Akademi Yayıncılık.

Büyüköztürk, Ş., Akgün, Ö. E., Demirel, F., Karadeniz, Ş. ve Çakmak, E. K. (2016). Bilimsel araştırma yöntemleri. Ankara: Pegem Akademi Yayıncılık.

Byo, J. (1990). Teach your instrumental students to listen. Music Educators Journal, 77(4), 43-46.

Cogdill, S. H. (2015). Applying research in motivation and learning to music education: What the experts say. Update: Applications of Research in Music Education, 33(2), 49-57.

Çelik, Z. (2006). Illköğretim ögrencilerinin başarı güdüleri ve ana baba beklentilerine ilişkin algıları. Yayımlanmamış doktora tezi, Dokuz Eylül Üniversitesi Eğitim Bilimleri Enstitüsü.

Çevik, D. B. (2011). Sınıf öğretmeni adaylarının müzik öğretimi özyeterlik düzeylerinin incelenmesi. Journal of Kırşehir Education Faculty, 12(1), 145-168.

Deniz-Nart, S. (2010). Deşifre şarkı söyleme ve koro eğitimine katkıları. Mehmet Akif Ersoy Üniversitesi Sosyal Bilimler Enstitüsü Dergisi, 2, 134-142.

Ellez, A. M. (2004). Etkin öğrenme, strateji kullanımı, matematik başarısı, güdü ve cinsiyet ilişkileri. Yayımlanmamış doktora tezi, Dokuz Eylül Üniversitesi Eğitim Bilimleri Enstitüsü.

Girgin, D. (2015). Bireysel Çalgı Dersi Motivasyon Ölçeği: geçerlik güvenirlik analizi. Kastamonu Ĕgitim Dergisi, 23(4), 1723-1736.

Göğüş, G. (2008). İlköğretim I. kademe müzik eğitiminde öğretmenin etkinliği. Uludă̆ Üniversitesi Ĕ̌itim Fakültesi Dergisi, 21(2), 369-382. 
Güleç, K. (2007, Eylül). Müziğin kişisel işlevleri açısından müzik eğitiminde güdülenmenin önemi. 38. Uluslararası Asya ve Kuzey Afrika Çalışmaları Kongresi'nde sunulan bildiri, Ankara.

Hatipoğlu, A. ve Kavas, E. (2016). Veli yaklaşımlarının öğretmen performansına etkisi. Itobiad: Journal of the Human \& Social Science Researches, 5(4), $1012-$ 1034.

Kebapcı, S. (2019). Azınlık ortaokulları ögrencilerinin evdeki müziksel ortamları ve müzik dersi yükleme değişkenleri arasındaki ilişkinin incelenmesi. Yayımlanmamış yüksek tezi, Marmara Üniversitesi Eğitim Bilimleri Enstitüsü.

Kılıç, I. (2009). İlköğretim birinci kademe sınıf öğretmenlerinin müzik öğretiminde karşılaştıkları sorunlar. İn̈̈n̈̈ Üniversitesi Eğitim Fakültesi Dergisi, 10(1), 123-138.

Kocaarslan, B. (2009). Genel müzik eğitimi alan ilköğretim ögrencilerinin müzik dersine ilişkin tutum, müzikal özgüven ve motivasyon düzeylerinin karşılaştırllması. Yayımlanmamış yüksek lisans tezi, Marmara Üniversitesi Eğitim Bilimleri Enstitüsü.

Kocabaş, A. (2000). Sınıf öğretmenlerinin müzik derslerindeki yetersizliklerine ilişkin görüşleri. Pamukkale Üniversitesi Eğitim Fakültesi Dergisi, 7(7), 7-11.

Kocabaş, A. ve Selçioğlu, E. (2006). İlköğretim okulları 4. ve 5. sinıflarında müzik dersinin gerçekleşme düzeyi ve öğrencilerin beklentilerine ilişkin görüşleri. Pamukkale Üniversitesi Ĕgitim Fakültesi Dergisi, 19(19), 59-69.

Kurtuldu, M. K. (2009). Sınıf öğretmeni adaylarının müzik öğretimi dersine yönelik tutumlarının değerlendirilmesi. Illkögretim Online, 8(2), 510-519.

McPherson, G. E., Osborne, M. S., Barrett, M. S., Davidson, J. W. ve Faulkner, R. (2015). Motivation to study music in Australian schools: The impact of music learning, gender, and socio-economic status. Research Studies in Music Education, 37(2), 141-160.

Nacakcı, Z. (2006, Nisan). İlköğretim öğrencilerinin müzik dersine ilişkin tutumları. Ulusal Müzik Eğitimi Sempozyumu'nda sunulan bildiri, Denizli: Pamukkale Üniversitesi.

Oğul, H. (2009). Okul öncesi öğretmen adaylarının temel ritim algllama ve şarkı söyleme becerilerinin incelenmesi. Yayımlanmamış doktora tezi, Selçuk Üniversitesi Sosyal Bilimleri Enstitüsü.

Otacıoğlu, S. G. (2007). İlköğretim 5. 6. 7. sınıf öğrencilerinin müzik dersine ilişkin tutumlarının incelenmesi. Dokuz Eylül Üniversitesi Buca Eğitim Fakültesi Dergisi, 21, 134-139.

Öz, N. B. (2001). İnsanın kültürel gelişiminde müzik eğitiminin önemi. Uludağ Üniversitesi Eğitim Fakültesi Dergisi, 14(1), 101-106.

Özdemir, G. ve Yıldız, G. (2010). Genel gelişim sürecinde müziksel gelişim. Mehmet Akif Ersoy Üniversitesi Sosyal Bilimler Enstitüsü Dergisi, 2(2), 77-90.

Özmenteş, S. (2005). Müzik eğitiminin boyutları ve çalgı eğitimi. İnönü Üniversitesi Eğitim Fakültesi Dergisi, 6(9), 89-98.

Özmenteş, S. (2012). İlköğretim öğrencilerinin evdeki müziksel ortamları, müzik dersine yönelik tutumları ve kişisel değişkenleri arasındaki ilişkiler. Eğitim ve Bilim, 37(163), 53-66.

Özmenteş, S. (2013). Çalg1 eğitiminde öğrenci motivasyonu ve performans. Ĕ̆itim ve Öğretim Araştırmaları Dergisi, 2(2), 320-331. 
Özmenteş, S. ve Özmenteş, G. (2009). Çalgı çalışmaya ilişkin tutum, bireysel özellikler ve performans düzeyi ilişkileri. Kastamonu Eğitim Dergisi, 17(1), 353-360.

Parkes, K. A., Jones, B. D. ve Wilkins, J. L. (2017). Assessing music students' motivation using the MUSIC Model of Academic Motivation Inventory. UPDATE: Applications of Research in Music Education, 35(3), 16-22.

Saka, D. ve Burak, S. (2016). Okul öncesi ve sınıf öğretmenleri adaylarının müzik ögretimindeki başarı ve başarısızlıklarına yönelik yüklemeleri. Ĕgitim ve Ö̆ retim Araştırmaları Dergisi, 5(3), 340-353.

Sichivitsa, V. O. (2007). The influences of parents, teachers, peers and other factors on students' motivation in music. Research Studies in Music Education, 29(1), 55-68.

Tanyeli, D. (2007). Illkögretim okullarında görev yapan müzik öğretmenlerinin müzik derslerinde karşılaştıkları sorunlar ve nedenlerine ilişkin görüşleri. Yayımlanmamış yüksek lisans tezi, Gazi Üniversitesi Eğitim Bilimleri Enstitüsü.

Uçan, A. (2005). Müzik eğitimi: temel kavramlar-ilkeler-yaklaşımlar ve Türkiye'deki durum. Ankara: Evrensel Müzikevi Yayınları.

Uluğbay, S. (2013). Müzik eğitiminin çocuk zekâsına olan etkileri. Kastamonu Ĕ̆itim Dergisi, 21(3), 1025-1034.

Uslu, M. (2006). Türkiye'de çalgı eğitiminin yaygınlaştırılmasında ve geliştirilmesinde çoksesli müzik eğitimi görüşü. Müzik ve Bilim Dergisi, 5, 1-10.

Yazıcı, T. (2012). İlköğretim müzik dersinin uygulanmasında karşılaşılan sorunların, öğretmen görüşleri açısından değerlendirilmesi (Trabzon ili örneği). Journal of the Cukurova University Institute of Social Sciences, 21(1), 185-200.

Youm, H. K. (2013). Parents' goals, knowledge, practices, and needs regarding music education for their young children in South Korea. Journal of Research in Music Education, 61(3), 280-302. 